EXPERIMENTAL STUDY

\title{
Expression profile of serotonin4 (5-HT4) receptors in adrenocortical aldosterone-producing adenomas
}

Dorthe Cartier, Sylvie Jégou, Françoise Parmentier ${ }^{1}$, Isabelle Lihrmann, Estelle Louiset, Jean-Marc Kuhn, Christian Bastard ${ }^{1}$, Pierre-François Plouin ${ }^{2}$, Michel Godin ${ }^{3}$, Hubert Vaudry and Hervé Lefebvre

INSERM U413, Laboratory of Cellular and Molecular Neuroendocrinology, European Institute for Peptide Research (IFRMP 23), Université de Rouen, 76821 Mont-Saint-Aignan, France, ${ }^{1}$ Laboratory of Oncologic Genetics, Centre Henri Becquerel, 76038 Rouen, France, ${ }^{2}$ Hypertension Unit, Université Paris-Descartes, Faculté de Médecine, AP-HP, Hôpital Européen Georges Pompidou, 75908 Paris cedex 15, France and ${ }^{3}$ Department of Nephrology, Centre Hospitalo-Universitaire de Rouen, 76031 Rouen, France

(Correspondence should be addressed to H Lefebvre; Email: herve.lefebvre@chu-rouen.fr)

\begin{abstract}
Objective: We aimed to investigate the expression profile of serotonin4 (5-HT4) receptors in adrenocortical aldosterone-producing adenoma (APA) tissues in comparison with normal adrenal cortex. Design and methods: Total 5-HT4 receptor mRNAs were quantified by real-time quantitative polymerase chain reaction (PCR) assay, and the mRNAs encoding the 5-HT4 receptor isoforms were characterized by reverse transcription (RT)-PCR in seven normal adrenal cortices and 11 APA tissues. The distribution of 5-HT4 receptor mRNAs was investigated by in situ hybridization in both normal adrenal and APA tissues, and the presence of 5-HT in APA tissues was studied by immunohistochemistry. Results: Real-time PCR analysis revealed that 5-HT4 receptor mRNA expression was 4.7-47 times higher in APA tissues than in normal glands. In situ hybridization studies showed that 5-HT4 receptor mRNAs were expressed in both zona glomerulosa and zona fasciculata/reticularis of the normal cortex and in groups of APA steroidogenic cells disseminated in the tumor tissues. Characterization of 5-HT4 receptor splice variants by RT-PCR revealed different profiles of expression in APAs versus normal adrenals. Isoforms (a) and (b) were not expressed in any APA but were present in the majority of normal adrenocortical tissues. Conversely, isoform (d) was expressed in 5/11 APAs but only in 1/7 adrenals. Immunohistochemical studies revealed the presence of 5-HT-immunoreactivity in both mast cells and clusters of steroidogenic cells in APA tissues.

Conclusion: Our results show overexpression and different splicing of the 5-HT4 receptor in APA tissues in comparison with normal adrenocortical tissue. They also demonstrate the presence of 5-HT in both mast cells and tumor steroidogenic cells, providing evidence for a possible autocrine/paracrine activation of aldosterone secretion within adenoma tissues.
\end{abstract}

European Journal of Endocrinology 153 939-947

\section{Introduction}

Serotonin (5-HT) exerts its physiologic effects through activation of several subtypes of $\mathrm{G}$ protein-coupled receptors, including the serotonin4 (5-HT4) receptor (for a review, see Hoyer et al. (1)). Several studies have shown that, in man, the 5-HT4 receptor primary transcript is alternatively spliced to produce eight receptor isoforms that differ in the length and structure of their C-terminal tail $(\mathrm{a}-\mathrm{g}, \mathrm{n})$ and one variant which exhibits a 14-amino-acid insertion within the second extracellular loop (h) $(2-5)$. Recently, a tenth isoform was cloned from the human pancreas and testis tissues and named 5-HT4(i) (6). This isoform contains a 40amino-acid insertion in the C-terminal tail of the previously known 5-HT4(b) receptor (6). All isoforms are positively coupled to adenylyl cyclase and selectively activated by substituted benzamide derivatives such as metoclopramide, cisapride and zacopride (2-6).
We have previously shown that, in the human adrenal gland, 5-HT stimulates aldosterone and cortisol secretion through activation of 5-HT4 receptors positively coupled to adenylyl cyclase and calcium influx (7-9). Reverse transcription (RT)-PCR studies have revealed that the human adrenal cortex expresses isoforms $(\mathrm{a}-\mathrm{d}, \mathrm{f}, \mathrm{h}$ and n) $(4,10)$. We have also found that 5 -HT can activate steroidogenesis in presumably autonomous adrenocortical lesions. An increased efficacy of 5-HT and/or 5-HT4 receptor agonists to stimulate steroidogenesis was even observed in some cases of adrenocorticotropic hormone (ACTH)-independent macronodular bilateral adrenal hyperplasia (AIMAH) and adrenocortical adenoma causing subclinical or overt Cushing's syndrome (10-12). In most cases, the hyperresponsiveness of AIMAH tissues to 5-HT4 receptor agonists can be accounted for by an overexpression of 5-HT4 receptors in comparison with normal adrenocortical tissue $(10,12)$, but the 5-HT4 receptor variants expressed by AIMAH tissues are identical to those present in normal adrenocortical 
tissue (10). Functional 5-HT4 receptors are also expressed in aldosterone-producing adenomas (APAs). Indeed, oral administration of the 5-HT4 receptor agonist cisapride to patients with APA causes an increase in plasma aldosterone levels (13). In addition, 5-HT and cisapride both stimulate aldosterone secretion from perifused APA explants (13). Finally, RT-PCR analysis has shown the presence of mRNA encoding the 5-HT4 receptor in APA extracts (13). However, the amounts of 5-HT4 receptor mRNA and the expression profile of 5-HT4 receptor isoforms have never been determined in APA tissues.

In the normal human adrenal cortex, perivascular mast cells can release substantial amounts of 5-HT, which is likely to enhance corticosteroid secretion through paracrine mechanisms $(7,14)$. The presence of 5-HT has also been detected by immunohistochemistry in adrenocortical cortisol-producing lesions, including AIMAHs and adenomas $(11,12)$. In these tissues, 5-HT-like immunoreactivity is localized in a subpopulation of steroidogenic cells. APAs have been shown to contain numerous mast cells (15), suggesting that 5-HT may be responsible for paracrine activation of aldosterone secretion by APA cells. However, the occurrence of 5-HT in APA tissues has never been investigated.

The aim of the present study was to investigate quantitatively and qualitatively the expression of the 5-HT4 receptor in both APA tissues removed from 11 patients and normal adrenal cortex. Quantitative RT-PCR was performed in order to compare the levels of expression of the 5-HT4 receptor in APA tissues with those of normal adrenal cortex. The distribution of the 5-HT4 receptor mRNA in both normal and aldosteronoma tissues was investigated by in situ hybridization, and the 5-HT4 receptor variants expressed by the tissues were characterized by RT-PCR and subsequently subcloned and sequenced. Finally, the possible occurrence of 5-HT within the adenoma tissues was investigated by immunohistochemistry.

\section{Materials and methods}

\section{Tissues, RNA extraction and real-time RT-PCR}

APA tissues were provided by a French endocrinologic network for collection of adrenocortical tumors
(Réseau COMETE, PHRC AOM 95 201) and stored at $-80^{\circ} \mathrm{C}$ until RNA extraction. Normal adrenal glands were obtained from seven patients undergoing expanded nephrectomy for kidney cancer. The protocol for collection of the tissues and the experimental procedures were approved by the regional and/or institutional ethics committees, and informed consent was obtained from all subjects. Total RNA from the 11 APAs and seven normal adrenal glands was extracted by the acid guanidium-thiocyanate-phenolchloroform procedure with Tri-Reagent (Sigma). The concentration of total RNA was determined by measuring the optical density at $260 \mathrm{~nm}$. Real-time RT-PCR analysis was carried out as described by Fink et al. (16) in order to quantify 5-HT4 receptor mRNA in both aldosteronoma and normal adrenal cortex. The primers and fluorogenic TaqMan probe used for these experiments hybridized to all 5-HT4 receptor splice variants (5-HT4pan) (Table 1). Briefly, $1 \mu \mathrm{g}$ total RNA from each tissue was converted to single-stranded cDNA using SuperScript II (Life Technologies, Eragny, France) with oligo (dT)12-18 primer $(0.5 \mu \mathrm{g} / \mathrm{ml})$, and the cDNA was diluted and aliquoted into microtiter plates. For each $25 \mu \mathrm{l}$ TaqMan reaction, $5 \mu \mathrm{l}$ cDNA were mixed with $1 \mu \mathrm{l}$ water, $12.5 \mu \mathrm{l}$ TaqMan Universal PCR Master Mix $\times 2$ (Applied Biosystems, Courtaboeuf, France), $2 \mu$ l sense primer $(2 \mu \mathrm{M}), 2 \mu \mathrm{l}$ antisense primer $(2 \mu \mathrm{M})$ and $2.5 \mu \mathrm{l}$ TaqMan probe $(2 \mu \mathrm{M})$. PCR parameters were $50{ }^{\circ} \mathrm{C}$ for $2 \mathrm{~min}, 95^{\circ} \mathrm{C}$ for $10 \mathrm{~min}, 40$ cycles of $95^{\circ} \mathrm{C}$ for $15 \mathrm{~s}$ and $60^{\circ} \mathrm{C}$ for $1 \mathrm{~min}$. Parallel assays using the same cDNA pools were carried out with primers and probe to the housekeeping gene porphobilinogen deaminase (PBGD) (Table 1). Quantitative RT-PCR was performed with the ABI Prism 7700 sequence detector system (Applied Biosystems) and analyzed with relative expression to PBGD, as previously described (16). Briefly, the level of expression in each sample was normalized by dividing copies/ng total RNA of 5-HT4 receptor gene by copies/ng total RNA of the housekeeping gene PBGD, and expressed as a percentage. This mode of calculation allows correction for both RNA quality and quantity. In each group of tissues, that is, normal and APAs, data are presented as mean土s.E.M.

Table 1 Real-time PCR analysis of 5-HT4 receptor mRNA.

\begin{tabular}{llcl}
\hline cDNA & Accession No. in GenBank & Primer & Sequence (5-3') \\
\hline $5-H T 4$ pan & Y 10437 & $\mathrm{~s}$ & AACGGCATCGATTTTTCACC \\
& & $\mathrm{as}$ & GTTCCTATAGACCAAAGGCTGGC \\
PBG-D & $\mathrm{p}$ & TGCTGCATTTCTCTGGATAGGTATTACGCC \\
& $\mathrm{s}$ & CTGCAACGGCGGAAGA \\
& & as & AGCTGGCTCTTGCGGGTAC \\
& $\mathrm{p}$ & CCCAAAGATGAGAGTGATTCGCGTGG \\
\hline
\end{tabular}

Oligonucleotide sequences for sense (s) and antisense (as) primers and TaqMan probes (p) are shown. 


\section{In situ hybridization}

Sense and antisense probes were prepared by in vitro transcription of a $1081 \mathrm{bp}$ fragment of the human 5-HT4 receptor cDNA encompassing exons I to V (position 3-1083; GenBank accession no. AJ 278982; this sequence is common to all 5-HT4 receptor isoforms) and subcloned in the pGEM-T vector (Promega). The probes were labeled with ${ }^{35}$ S-UTP (Amersham), using the Riboprobe Combination System (Promega). Frozen tissue sections $(12-\mu \mathrm{m}$-thick) were initially fixed in cold $4 \%$ paraformaldehyde for $10 \mathrm{~min}$, delipidized in chloroform and dehydrated in graded alcohols. Then, sections were acetylated, treated with Triton X-100 $(0.2 \%)$, rinsed in $2 \times$ standard saline citrate (SSC) and prehybridized at $55^{\circ} \mathrm{C}$ for $1 \mathrm{~h}$ in the following buffer: $50 \%$ formamide, $0.6 \mathrm{M} \mathrm{NaCl}, 10 \mathrm{mM}$ Tris- $\mathrm{HCl}$ (pH 7.5), 0.02\% Ficoll, $0.02 \%$ polyvinylpyrrolidone, $0.2 \%$ BSA, $1 \mathrm{mM}$ EDTA ( $\mathrm{pH} 8$ ), $550 \mu \mathrm{g} / \mathrm{ml}$ denatured salmon sperm DNA and $50 \mu \mathrm{g} / \mathrm{ml}$ yeast tRNA. Hybridization was performed overnight, at $55^{\circ} \mathrm{C}$, in the same buffer (except for salmon sperm DNA, the concentration of which was lowered to $60 \mu \mathrm{g} / \mathrm{ml}$ ) supplemented with $10 \mathrm{mM}$ dithiothreitol, $10 \%$ dextran sulfate and heatdenaturated riboprobes $\left(1.5 \times 10^{7}\right.$ c.p.m. $\left./ \mathrm{ml}\right)$. Posthybridization washes were performed in $2 \times \mathrm{SSC}$ at $55^{\circ} \mathrm{C}$ for $30 \mathrm{~min}$, followed by treatment with RNase A $(50 \mu \mathrm{g} / \mathrm{ml})$ at $37^{\circ} \mathrm{C}$ for $1 \mathrm{~h}$, and by five final stringent washes in $0.1 \times \mathrm{SSC}$ at $60^{\circ} \mathrm{C}$. After dehydration in graded alcohols containing ammonium acetate, the sections were dipped into Kodak NTB2 emulsion, exposed for 6 weeks and counterstained with hematoxylin. Sections were observed with an Eclipse E600 microscope equipped with a CCD DXC950 camera (Nikon, Les Ulis, France).

\section{Characterization of 5-HT4 receptor isoforms by RT-PCR}

Total RNA was extracted and reverse transcribed as described above. Amplification of the cDNAs encoding the different 5-HT4 receptor C-terminal splice variants was performed by PCR using primer S1 (Table 2), which hybridizes to all 5-HT4 receptor messengers, and splice variant-specific reverse primers (Table 2 and Fig. 1). The 5-HT4(h) variant was amplified with the forward primer Fwh, which is specific for cDNAs containing the 5-HT4(h) exon, and the reverse primer Revh, which hybridizes to all 5-HT4 receptor messengers. All PCR-based procedures were performed in a final volume of $50 \mu \mathrm{l}$ containing $10 \%$ of RT mixture, 3 U DNA Taq polymerase (Life Technologies), DNA polymerase buffer (Life Technologies), $1.5 \mathrm{mM} \mathrm{MgCl}_{2}, 0.4 \mathrm{mM}$ dNTP and $20 \mathrm{pmol}$ of each primer. The PCR reactions were performed for 40 cycles $\left(94^{\circ} \mathrm{C}, 40 \mathrm{~s} ; 50^{\circ} \mathrm{C}\right.$, $\left.60 \mathrm{~s} ; 72{ }^{\circ} \mathrm{C}, 90 \mathrm{~s}\right)$. The PCR products were analyzed in $1.5 \%$ agarose gels, blotted on a nylon membrane and hybridized with the $\left[{ }^{32} \mathrm{P}\right]$ ATP-labeled oligonucleotide S2. In addition, PCR products were subcloned into pGEM-T (Promega) and sequenced, using the Thermosequenase kit (Amersham), on a Li-Cor 4200L DNA sequencer (ScienceTec, Les Ulis, France) with fluorescent T7 and T3 primers (MWG-Biotech, Courtaboeuf, France).

\section{Immunohistochemistry}

Deparaffinized sections from APA tissues were incubated overnight at $4{ }^{\circ} \mathrm{C}$ in a humidified atmosphere with polyclonal rabbit antibodies directed against 5-HT (1:400; Sigma). The sections were then incubated with a streptavidin-biotin-peroxidase complex (Dako, Carpinterla, CA, USA), and the enzymatic activity was revealed with diaminobenzidine. The specificity of the immunoreaction was controlled by using 5-HT-antisera preabsorbed for $2 \mathrm{~h}$ at $20^{\circ} \mathrm{C}$ with $10^{-6} \mathrm{M} 5$-HT. The tissue sections were counterstained for $1 \mathrm{~min}$ with hematoxylin, mounted in Eukitt (Kindler, Freiburg, Germany), cover-slipped, and examined on an Eclipse E-600 microscope equipped with a CCD DXC950 camera.

Table 2 Oligonucleotide sequences of sense and antisense primers used for RT-PCR analysis of 5-HT4 receptor isoform mRNAs.

\begin{tabular}{lll}
\hline Primer & Accession No. in GenBank & \multicolumn{1}{c}{ Sequence (5-3') } \\
\hline Fwh & AJ243213 & GAAAGGAGTCTAAACCAAGGCCTGG \\
Revh & AJ243213 & CATGTGTGGATCCATTAATGGTTGTGG \\
Fw1 & Y10437 & AATTGATTTGATAGAAAAGAGGAA \\
Reva & Y08756 & GTATGGGCAGTTCTCGAGTTCCTGATGATG \\
Revb & GAAGTTGCTGGCGGGTGACACTGACTCTC \\
Reve & Y12505 & GGCATTAGGATGGTTTGGTCAATC \\
Revc & CATCCAATGATTTATTTGATAACTTCAG \\
Reve & AJ011371 & CAGACGGGAACAGGTCTATTGCAGAAG \\
Revf & AJ243213 & TTAGACGGGAACAGGTCTTAGTACATG \\
Revg & AJ243213 & CAGAAGAGCAGGAGGAAGCTGGAGACAG \\
Revn & AJ278982 & ACTGGAGCATTACCCCTTCTGAG \\
Revi & AJ131726 & AAGACAGGCTTCCTTGCAGTCAAACATC \\
S2 & Y10437 & CCCTGGGCAGGTGTGGACTGC \\
\hline
\end{tabular}




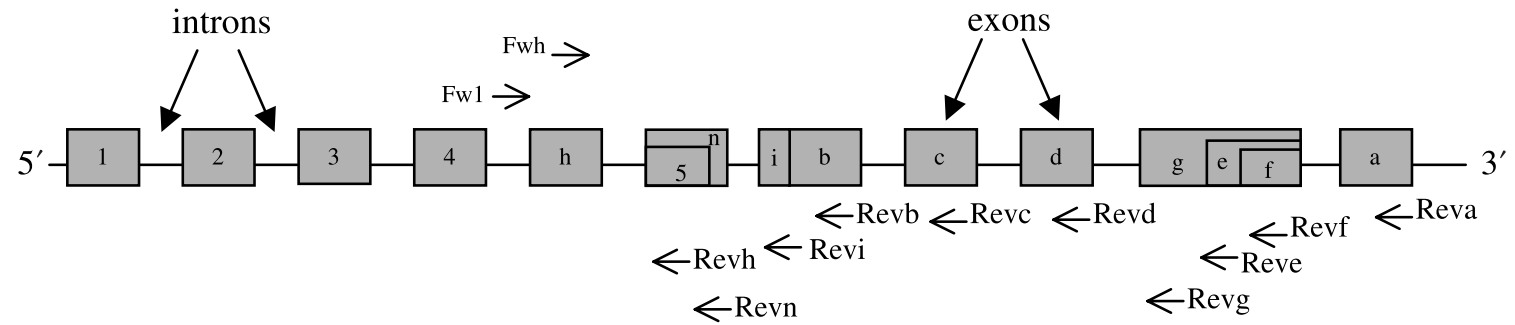

Figure 1 Schematic representation of the human 5-HT4 receptor gene showing the position of the primers used to amplify the 5-HT4 receptor transcripts.

\section{Results}

Quantitative expression of 5-HT4 receptors in normal adrenal glands and hyperplasias

The relative amounts of 5-HT4 receptor mRNAs in normal adrenal cortex and aldosteronoma tissues were determined by real-time RT-PCR. When expressed as arbitrary units normalized to PBGD, 5-HT4 receptor levels ranged from $0.48 \%$ to $3.72 \%$ (mean 2.13 $\pm 0.46 \%$ ) in normal adrenal glands vs 9.9-99.3\% (mean 46.9 $\pm 9.4 \%$ ) in APAs (Fig. 2).

\section{Distribution of 5-HT4 receptor $\mathrm{mRNA}$ in normal adrenal cortex and APA tissues}

In situ hybridization histochemistry showed that, in the normal adrenal cortex, 5-HT4 receptor mRNA is primarily expressed in the zona glomerulosa (Fig. 3A and B). A weaker hybridization signal was also visualized in some cords of zona fasciculata/reticularis cells (Fig. 3A and B). Incubation of normal adrenal tissue sections with the sense riboprobe did not produce any staining in the zona glomerulosa nor in the zona

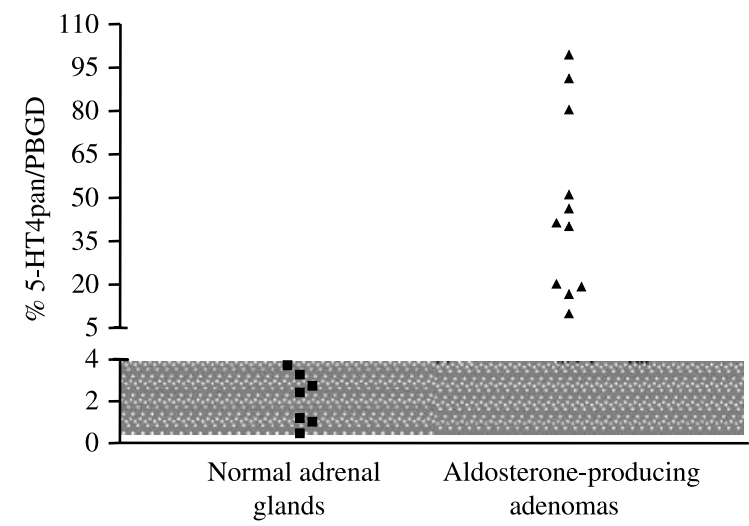

Figure 2 Expression levels of 5-HT4 receptor mRNAs in seven normal human adrenal cortices and 11 APA tissues. TaqMan RT-PCR analysis was carried out with primers and a fluorogenic probe that recognized all 5-HT4 splice variants (5-HT4pan; see Table 3 for oligonucleotide sequences). 5-HT4 receptor mRNA expression is in arbitrary units normalized to PBGD. The shaded area corresponds to the range of variation of expression levels observed in normal tissues. fasciculata/reticularis. In contrast, labeling was observed in the capsule and was thus considered nonspecific (Fig. 3C). Incubation of APAs with the antisense probe produced a more intense and diffuse labeling than in the adrenal cortex (Fig. $4 \mathrm{~A}$ and B). At a higher magnification, the hybridization signal was seen in groups of cells disseminated in the tissue and frequently arranged in acini (Fig. 4C). No labeling was observed when adjacent sections were incubated with the sense riboprobe (Fig. 4D).

\section{Characterization of 5-HT4 receptor isoforms by RT-PCR}

RT-PCR amplification was applied to characterize 5-HT4 receptor isoforms in both normal adrenal glands and APAs (Table 3). Isoforms (a) and (b), which were expressed in most normal adrenal extracts, were not detected in any of the APAs studied. Isoform (f), which was found in all normal adrenal cortices, occurred in only 5/11 APAs. In contrast, isoform (d) was more frequently expressed in APA tissues than in the normal cortex (5/11 vs $1 / 7$ respectively). The profiles of expression of 5-HT4 receptor isoforms (c), (e), (g), (h) and (n) were globally similar in APAs and normal cortex. Indeed, isoform (c) was expressed in 10/11 APAs and all normal cortices, and isoform (n) was found in all extracts; in contrast, isoforms (e), (g) and (h) were not detected in any of the tissues studied. We have also looked for the expression of isoform (i), which was identified while this study was in progress (6), in three normal adrenal cortices and the series of APAs. Isoform (i) mRNA was detected in one adrenal gland but did not occur in any APA (data not shown).

\section{Immunohistochemical detection of 5-HT in APA tissues}

Incubation of APA slices with 5-HT antibodies revealed the presence of immunopositive cells disseminated in the whole tissue (Fig. 5A). The immunoreactive material was detected in isolated mast cells (Fig. 5B), as previously observed in the normal adrenal cortex (7). 5-HT-like immunoreactivity was also detected in a subpopulation of steroidogenic cells presenting as spongiocytic or 

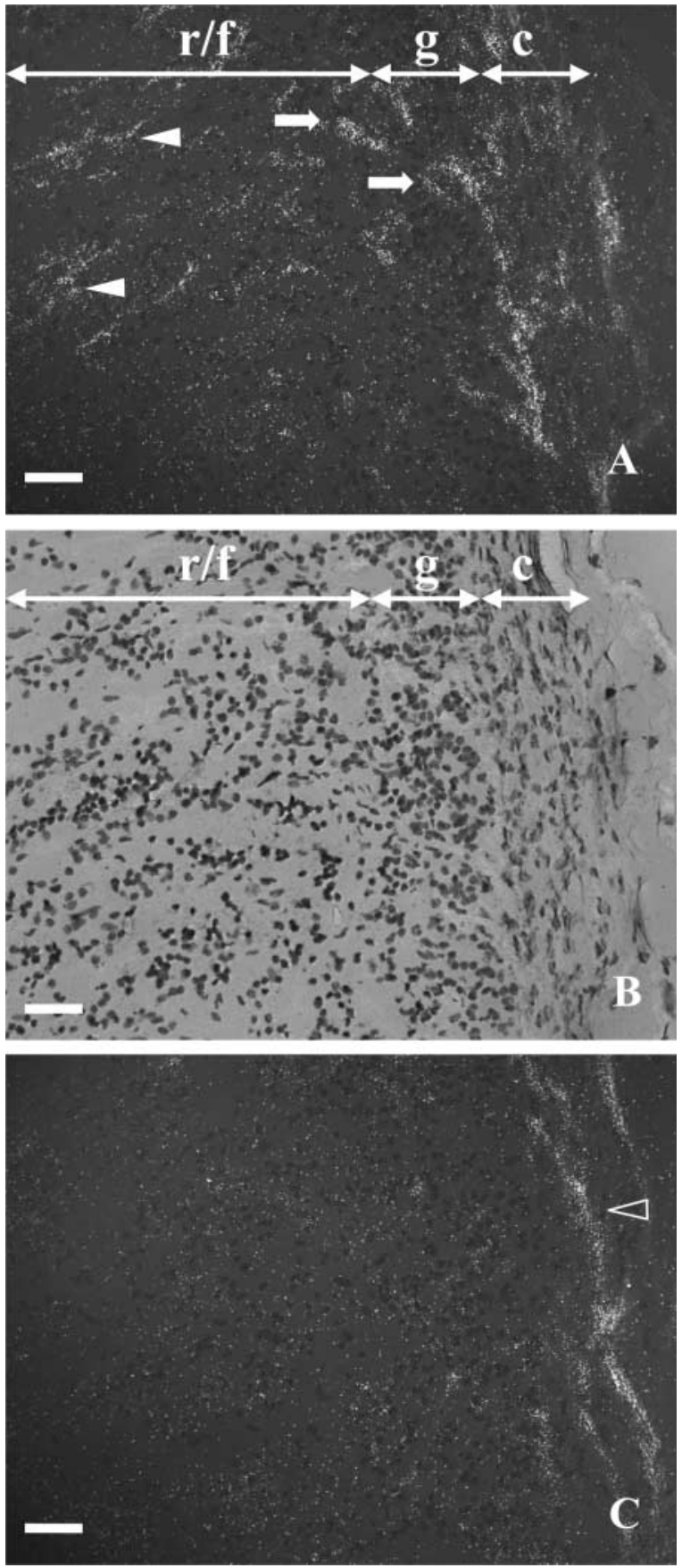

Figure 3 Localization of 5-HT4 receptor gene expression by in situ hybridization in the normal adrenal cortex. (A) Microphotograph under epipolarization showing a positive hybridization signal in the capsule (c) and the zona glomerulosa (g; arrows), and a more sparse signal in some cords of zona fasciculata/reticularis cells (r/f; arrowheads). (B) Bright-field microphotographs of the same area of the adrenal cortex. (C) No labeling was observed in the zona glomerulosa and zona fasciculata/reticularis after incubation with the 5-HT4 receptor sense riboprobe, while staining was still noticed in the capsule (arrowhead). Scale bars: $50 \mu \mathrm{m}$.

compact cells (Fig. 5C). Preincubation of the 5-HT antiserum with 5-HT $\left(10^{-6} \mathrm{M}\right)$ totally abolished immunostaining (data not shown).

\section{Discussion}

We have previously observed that APA tissues express functional 5-HT4 receptors in very much the same way as the normal adrenal gland (13). We now show that, like the ACTH receptor (17), the 5-HT4 receptor is markedly overexpressed in APAs in comparison with the normal adrenocortical tissue. Interestingly, the mean relative amount of 5-HT4 receptor mRNA in APAs, that is, $46.9 \%$, in arbitrary units normalized to PBGD, is also higher than that formerly reported in six 5-HT4 receptor agonist-responsive AIMAHs $(13.1 \%)$ and two unilateral adenomas $(3.78 \%$ and $13.6 \%$ respectively) causing Cushing's syndrome $(10,12)$. This latter observation suggests that high expression of 5-HT4 receptors, like high expression of aldosterone synthase (18), may be a characteristic of aldosterone-secreting adrenocortical tissues. We then performed in situ hybridization studies in order to investigate the distribution of 5-HT4 receptor mRNAs in both normal adrenal gland and APAs. The results indicate that, in the adrenal cortex, 5-HT4 receptor mRNAs are intensely expressed in the zona glomerulosa and in only scattered cords of zona fasciculata/reticularis cells. Conversely, we observed that 5-HT4 receptor mRNAs are strongly expressed in a majority of APA cells. As the zona glomerulosa represents only a minor part of the adrenal cortex, this observation probably explains overexpression of total 5-HT4 receptor mRNAs in APAs as compared with the normal adrenocortical tissue. The predominant expression of 5-HT4 receptor mRNAs in the zona glomerulosa is also consistent with previous studies showing that 5-HT4 receptor agonists are much more potent in stimulating in vitro aldosterone than cortisol secretion from normal adrenocortical explants (19). Collectively, the results of real-time PCR and in situ hybridization studies suggest that high expression of 5-HT4 receptors by normal and tumor adrenocortical cells is a feature of glomerulosal differentiation.

Previous studies have shown that, in COS-7 cells transfected with 5-HT4 receptors, both basal and 5-HT4 receptor agonist-stimulated cAMP productions increase as a function of receptor density (20). It would thus be expected that overexpression of 5-HT4 receptor mRNA by APA tissues would induce increased responsiveness of these tumors to 5-HT4 receptor agonists. In fact, we have previously observed that, in patients with APA, the amplitude of the plasma aldosterone response to the 5-HT4 receptor agonist cisapride (that is, $+133 \%$ of basal level, a value calculated from previously published data (13)) is lower than that observed in healthy subjects $(+232 \%$ of basal level, a value calculated from previously published data (21)). The apparent discrepancy between the 5-HT4 receptor expression data and the results of clinical studies may be ascribed to the fact that only part of the 5-HT4 receptor mRNAs is translated into functional proteins in APA tissues. It could also 

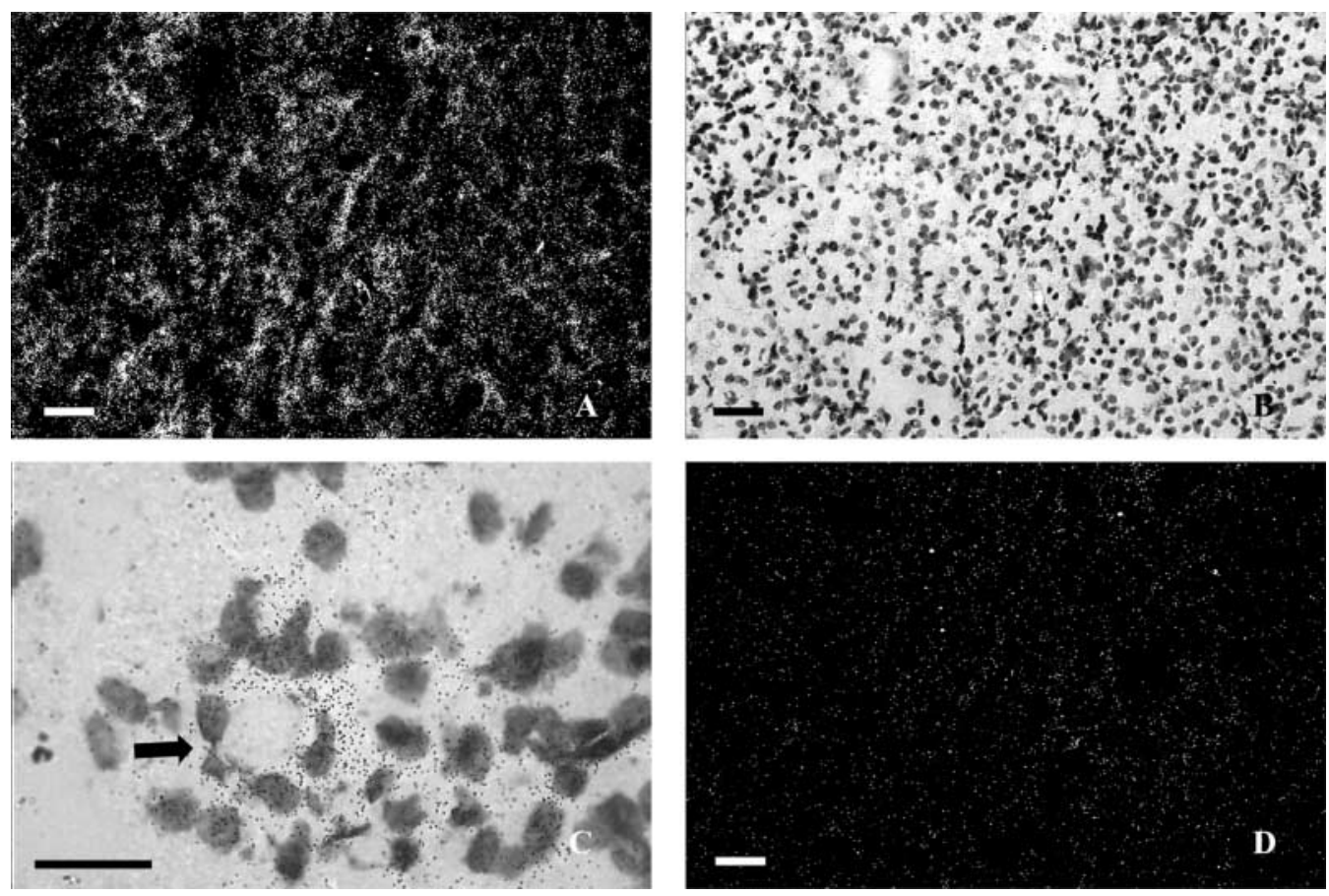

Figure 4 Localization of 5-HT4 receptor gene expression by in situ hybridization in APA tissues. (A) Representative dark-field microphotograph showing intense staining of the tissue. (B) Bright-field microphotograph of the same area of the APA tissue. (C) A strong hybridization signal was observed in clusters of cells frequently arranged in acini (arrow). (D) No labeling was observed in the same region of the tissue after incubation with the 5-HT4 receptor sense riboprobe. Scale bars: A, B and D, $50 \mu \mathrm{m} ; \mathrm{C}, 25 \mu \mathrm{m}$.

be attributable to disparities in the expression profiles of 5-HT4 receptor splice variants, which may result in functional variability in 5-HT4 receptor-mediated tissue responses. Indeed, it is now well established that the diverse 5-HT4 receptor isoforms may activate different transduction pathways in addition to adenylyl cyclase (for a review, see Bockaert et al. (22)). 5-HT4 receptor isoforms may also form homo- and/or heterodimers that may possess distinct pharmacologic and/or biochemical characteristics, as already shown for other G-protein-coupled receptors (23-25). We have thus characterized the 5-HT4 receptor isoforms expressed by APA tissues and normal adrenal cortex. APAs were found to exhibit an expression profile of 5-HT4 receptor splice variants different from that of the normal adrenal cortex. In particular, APAs do not express isoforms (a) and (b) which are frequently present in normal adrenocortical tissues. Beside their ability to

Table 3 RT-PCR analysis of 5-HT4 receptor isoform (a-h, n) mRNAs in the 11 APAs (A1-A11) and seven normal adrenals (N1-N7).

\begin{tabular}{|c|c|c|c|c|c|c|c|c|c|}
\hline & $a$ & b & c & $d$ & e & $f$ & $g$ & $\mathrm{~h}$ & $\mathrm{n}$ \\
\hline A1 & - & - & + & + & - & + & - & - & + \\
\hline A2 & - & - & + & - & - & + & - & - & + \\
\hline A3 & - & - & + & + & - & + & - & - & + \\
\hline A4 & - & - & + & - & - & + & - & - & + \\
\hline A5 & - & - & + & + & - & - & - & - & + \\
\hline A6 & - & - & - & - & - & - & - & - & + \\
\hline A7 & - & - & + & + & - & - & - & - & + \\
\hline A8 & - & - & + & - & - & - & - & - & + \\
\hline A9 & - & - & + & + & - & + & - & - & + \\
\hline A10 & - & - & + & - & - & - & - & - & + \\
\hline A11 & - & - & + & - & - & - & - & - & + \\
\hline N1 & + & + & + & - & - & + & - & - & + \\
\hline N2 & + & + & + & + & - & + & - & - & + \\
\hline N3 & + & - & + & - & - & + & - & - & + \\
\hline N4 & - & - & + & - & - & + & - & - & + \\
\hline N5 & + & + & + & - & - & + & - & - & + \\
\hline N6 & + & + & + & - & - & + & - & - & + \\
\hline N7 & + & + & + & - & - & + & - & - & + \\
\hline
\end{tabular}



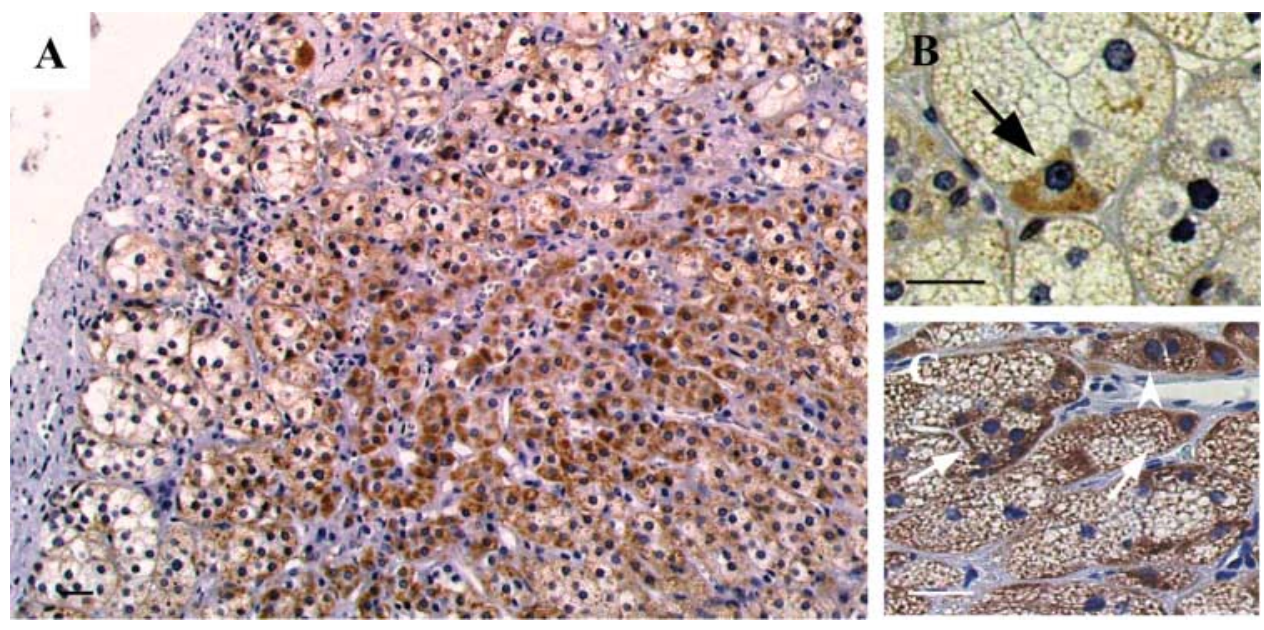

Figure 5 Immunohistochemical localization of 5-HT in APA tissues. (A) Lowmagnification microphotograph showing groups of 5-HT-immunoreactive cells disseminated in APA tissue. (B) Close-up view of an isolated immunopositive mast cell (arrow). (C) Photomicrograph showing 5-HT-like immunoreactivity in large, lipid-loaded spongiocytic cells (arrows) and compact steroidogenic cells (arrowhead). Scale bars: $25 \mu \mathrm{m}$ activate the $\mathrm{G} \alpha \mathrm{S}$ protein, isoforms (a) and (b) are known to establish additional coupling mechanisms, probably leading to a more efficient transduction of the message. For instance, isoform (a) can also activate heterotrimeric G $\alpha 13$ protein, while isoform (b) can stimulate the MAPkinase pathway, which is involved in calcium-induced aldosterone secretion (26-28). The loss of isoforms (a) and (b) may therefore reduce the efficacy of 5-HT4 receptor agonists to stimulate aldosterone secretion in patients with APA. Similarly, the fact that isoform (d) is more frequently expressed in APAs than in normal tissues may account for the decreased steroidogenic response to cisapride, as this variant is more rapidly desensitized by 5-HT4 receptor agonists than the other isoforms (29). Conversely, it is difficult to evaluate the functional consequences of the loss of isoform (i) and the less frequent isoform (f) expression in APAs, as compared with the normal cortex, since the transduction mechanisms associated with these variants have not yet been fully elucidated. In summary, the characterization of the expression profile of 5-HT4 receptor isoforms in all the tissues studied has revealed that, unlike normal adrenals, APA cells preferentially express splice variants which are potentially less effective to induce the steroidogenic response. This observation may explain why the amplitude of cisapride-induced aldosterone secretion is higher in healthy volunteers than in APA patients despite overexpression of total 5-HT4 receptor mRNA in the tumor tissues. The unusual splicing of the 5-HT4 receptor pre-mRNA in APA cells may be considered a celladaptive mechanism aimed at limiting the stimulatory effect of 5-HT and subsequently the degree of hyperaldosteronism.

Biochemical and immunohistochemical studies have demonstrated that, in the normal adrenal cortex, 5-HT is exclusively stored and released by perivascular mast cells $(7,14)$. In cortisol-producing adrenocortical lesions, including bilateral macronodular hyperplasias and adenomas, 5-HT-like immunoreactivity is found in the cytoplasm of a subpopulation of steroidogenic cells
$(11,12)$. It has also been shown that APAs contain numerous mast cells (15). The present study now indicates that, in APAs, 5-HT is located in both mast cells and groups of steroidogenic cells, suggesting that 5-HT concentration in APA tissues is probably higher than in normal adrenal cortex. In addition, the detection of 5HT in APA spongiocytic cells provides further evidence of the presence of hybrid cells, that is, those exhibiting both steroidogenic and neuroendocrine cell characteristics, in adrenocortical lesions $(11,12,30,31)$. These observations indicate that 5-HT may exert a tonic stimulatory effect on aldosterone secretion through an autocrine/paracrine mode of regulation and thus may play a significant role in the pathophysiology of APAs. In particular, 5-HT, together with other adenylyl cyclase-activating regulatory factors such as ACTH and luteinizing hormone, may participate in the previously shown overexpression of aldosterone synthase in APA tissues (18) through stimulation of the transcription factors Nurr1 and Nurr77 (17, 32-34).

In conclusion, the present study has shown that aldosterone-producing adenomas overexpress the 5-HT4 receptor as compared with the normal adrenal cortex. Our results also demonstrate the existence of different splicing of the 5-HT4 receptor transcript in APA. Finally, the data show for the first time that APAs produce 5-HT on their own, providing evidence of autocrine/paracrine regulation of aldosterone secretion within the tumor tissues. Collectively, these observations suggest that selective 5-HT4 receptor antagonists may represent a new approach in the treatment of primary hyperaldosteronism.

\section{Acknowledgements}

This work was supported by the Conseil Régional de HauteNormandie, IFRMP 23, INSERM U413, the CHU de Rouen, and the Réseau COMETE (PHRC AOM 95 201). 


\section{References}

1 Hoyer D, Clarke DE, Fozard JR, Hartig PR, Martin GR, Mylecharane EJ, Saxena PR \& Humphrey PP. International Union of Pharmacology classification of receptors for 5-hydroxytryptamine (serotonin). Pharmacological Reviews 199446 157-203.

2 Blondel O, Vandecasteele G, Gastineau M, Leclerc S, Dahmoune Y, Langlois M \& Fischmeister R. Molecular and functional characterization of a 5-HT4 receptor cloned from human atrium. FEBS Letters $1997 \mathbf{4 1 2} 465-474$

3 Blondel O, Gastineau M, Dahmoune Y, Langlois M \& Fischmeister R. Cloning, expression, and pharmacology of four human 5-hydroxytryptamine4 receptor isoforms produced by alternative splicing in the carboxyl terminus. Journal of Neurochemistry $1998702252-2261$.

4 Bender E, Pindon A, Van Oers I, Zhang YB, Gommeren W, Verhasselt P, Jurzak M, Leysen J \& Luyten W. Structure of the human serotonin 5-HT4 receptor gene and cloning of a novel 5-HT4 splice variant. Journal of Neurochemistry $2000 \mathbf{7 4} 478$-489.

5 Vilaro MT, Domenech T, Palacios JM \& Mengod G. Cloning and characterization of a novel human 5-HT4 receptor variant that lacks the alternatively spliced carboxy terminal exon. RT-PCR distribution in human brain and periphery of multiple 5-HT4 receptor variants. Neuropharmacology $2002 \mathbf{4 2} 60-73$.

6 Brattelid T, Kvingedal AM, Krobert KA, Andressen KW, Bach T, Hystad ME, Kaumann AJ \& Levy FO. Cloning, pharmacological characterisation and tissue distribution of a novel 5-HT4 receptor splice variant, 5-HT4(i). Naunyn-Schmiedeberg's Archives of Pharmacology $2004369616-628$.

7 Lefebvre H, Contesse V, Delarue C, Feuilloley M, Héry F, Grise P, Raynaud G, Verhofstad AAJ, Wolf LM \& Vaudry H. Serotonininduced stimulation of cortisol secretion from human adrenocortical tissue is mediated through activation of a serotonin 4 receptor subtype. Neuroscience $1992 \mathbf{4 7} 999-1007$.

8 Hamel C, Contesse V, Delarue C, Lefebvre H \& Vaudry H. Transduction mechanisms associated with activation of adrenal 5-HT4 receptors in amphibians and humans. Annales d'Endocrinologie (Paris) 199657 PO92.

9 Contesse V, Lefebvre H, Lenglet S, Kuhn JM, Delarue C \& Vaudry H. Role of 5-HT in the regulation of the brain-pituitary-adrenal axis: effects of 5-HT on adrenocortical cells. Canadian Journal of Physiology and Pharmacology $2000 \mathbf{7 8}$ 967-983.

10 Cartier D, Lihrmann I, Parmentier F, Bastard C, Bertherat J, Caron P, Kuhn JM, Lacroix A, Tabarin A, Young J, Vaudry H \& Lefebvre H. Overexpression of serotonin4 receptors in cisaprideresponsive adrenocorticotropin-independent bilateral macronodular hyperplasia causing Cushing's syndrome. Journal of Clinical Endocrinology and Metabolism $2003 \mathbf{8 8} 248-254$.

11 Bertherat J, Contesse V, Louiset E, Barrande G, Duparc C, Groussin L, Emy P, Bertagna X, Kuhn JM, Vaudry H \& Lefebvre $\mathrm{H}$. In vivo and in vitro screening for illegitimate receptors in ACTH-independent macronodular adrenal hyperplasia (AIMAH) causing Cushing's syndrome: identification of two cases of gonadotropin/gastric inhibitory polypeptide-dependent hypercortisolism. Journal of Clinical Endocrinology and Metabolism $2005901302-1310$.

12 Contesse V, Reznik Y, Louiset E, Duparc C, Cartier C, Sicard F, Laquerrière A, Parmentier F, Kuhn JM, Vaudry H \& Lefebvre H. Abnormal sensitivity of cortisol-producing adrenocortical adenomas to serotonin: in vivo and in vitro studies. Journal of Clinical Endocrinology and Metabolism 200590 2843-2850.

13 Lefebvre H, Cartier D, Duparc C, Lihrmann I, Contesse V, Delarue C, Godin M, Fischmeister R, Vaudry H \& Kuhn JM. Characterization of serotonin4 (5-HT4) receptors in adrenocortical aldosterone-producing adenomas: in vivo and in vitro studies. Journal of Clinical Endocrinology and Metabolism 2002 87 1211-1216.

14 Lefebvre H, Compagnon P, Contesse V, Delarue C, Thuillez C, Vaudry H \& Kuhn JM. Production and metabolism of serotonin (5-HT) by the human adrenal cortex: paracrine stimulation of aldosterone secretion by 5-HT. Journal of Clinical Endocrinology and Metabolism $2001865001-5007$.

15 Aiba M, Iri H, Suzuki H, Kageyama K, Kawai T, Abe O, Murai M, Tazaki H \& Saruta T. Numerous mast cells in an 11-deoxycorticosterone-producing adrenocortical tumor. Histologic evaluation of benignancy and comparison with mast cell distribution in adrenal glands and neoplastic counterparts of 67 surgical regimens. Archives of Pathology and Laboratory Medicine 1985109 357-360.

16 Fink L, Seeger W, Ermert L, Hänze J, Stahl U, Grimminger F, Kummer W \& Bohle RM. Real-time quantitative RT-PCR after laser-assisted cell picking. Nature Medicine 19984 1329-1333.

17 Arnaldi G, Mancini V, Costantini C, Giovagnetti M, Petrelli M, Masini A, Bertagna X \& Mantero F. ACTH receptor mRNA in human adrenocortical tumors: overexpression in aldosteronomas. Endocrine Research 199824 845-849.

18 Fallo F, Pezzi V, Barzon L, Mulatero P, Veglio F, Sonino N \& Mathis JM. Quantitative assessment of CYP11B1 and CYP11B2 expression in aldosterone-producing adenomas. European Journal of Endocrinology 2002147 795-802.

19 Lefebvre H, Contesse V, Delarue C, Soubrane C, Legrand A, Kuhn JM, Wolf LM \& Vaudry H. Effect of the serotonin-4 receptor agonist zacopride on aldosterone secretion from the human adrenal cortex. In vivo and in vitro studies. Journal of Clinical Endocrinology and Metabolism 199377 1662-1666.

20 Claeysen S, Sebben M, Bécamel C, Eglen RM, Clark RD, Bockaert J \& Dumuis A. Pharmacological properties of 5-hydroxytryptamine4 receptor antagonists on constitutively active wild-type and mutated receptors. Molecular Pharmacology 200058 136-144.

21 Lefebvre H, Contesse V, Delarue C, Legrand A, Kuhn JM, Vaudry H \& Wolf LM. The serotonin4 receptor agonist cisapride and angiotensin II exert additive effects on aldosterone secretion in normal man. Journal of Clinical Endocrinology and Metabolism $199580504-507$.

22 Bockaert J, Claeysen S, Compan V \& Dumuis A. 5-HT4 receptors. Current Drug Targets. CNS and Neurological Disorders $2004339-51$.

23 Jordan BA \& Devi LA. G-protein-coupled receptor heterodimerization modulated receptor function. Nature $1999399697-700$.

24 Lee SP, Xie Z, Varghese G, Nguyen T, O'Dowd BF \& George SR. Oligomerization of dopamine and serotonin receptors. Neuropsychopharmacology 200023 S32-S40.

25 Berthouze M, Ayoub M, Russo O, Rivail L, Sicsic S, Fischmeister R, Berque-Bestel F, Jockers R \& Lezoualc'h F. Constitutive dimerization of human serotonin 5-HT4 receptors in living cells. FEBS Letters $2005 \mathbf{5 7 9} 2973-2980$.

26 Ponimaskin EG, Profirovic J, Vaiskunaite R, Richter DW \& VoynoYasenetskaya TA. 5-Hydroxytryptamine 4(a) receptor is coupled to the Galpha subunit of heterotrimeric G13 protein. Journal of Biological Chemistry $200227720812-20819$.

27 Startchik I, Morabito D, Lang U \& Rossier MF. Control of calcium homeostasis by angiotensin II in adrenal glomerulosa cells through activation of p38 MAPK. Journal of Biological Chemistry $200227724265-24273$.

28 Norum JH, Hart K \& Levy FO. Ras-dependent ERK activation by the human G(s)-coupled serotonin receptors 5-HT4(b) and 5HT7(a). Journal of Biological Chemistry 2003278 3098-3104.

29 Mialet J. Fischmeister R \& Lezoualc'h F. Characterization of human 5-HT4(d) receptor desensitization in CHO cells. British Journal of Pharmacology 2003138 445-452.

30 Hiroi N, Chrousos GP, Kohn B, Lafferty A, Abu-Asab M, Bonat S, White A \& Bornstein SR. Adrenocortical-pituitary hybrid tumor causing Cushing's syndrome. Journal of Clinical Endocrinology and Metabolism 200186 2631-2637.

31 Lefebvre H, Duparc C, Chartrel N, Jegou S, Pellerin A, Laquerriere A, Ivell R, Vaudry H \& Kuhn JM. Intraadrenal adrenocorticotropin production in a case of bilateral macronodular adrenal hyperplasia causing Cushing's syndrome. Journal of Clinical Endocrinology and Metabolism $2003 \mathbf{8 8} 3035-3042$.

32 Davis IJ \& Lau LF. Endocrine and neurogenic regulation of the orphan nuclear receptors Nur77 and Nurr-1 in the adrenal glands. Molecular and Cellular Biology 199414 3469-3483. 
33 Lu L, Suzuki T, Yoshikawa Y, Murakami O, Miki Y, Moriya T, Bassett MH, Rainey WE, Hayashi Y \& Sasano H. Nur-related factor 1 and nerve growth factor-induced clone B in human adrenal cortex and its disorders. Journal of Clinical Endocrinology and Metabolism $2004894113-4118$.

34 Amigh, KS, Mayhew, BA, Mantero, F, Schiavi, F, White, PC \& Rainey, WE. Aberrant expression of luteinizing hormone receptor in an aldosterone-producing adenoma and its regulation of aldos- terone synthase expression. Abstract OR 56-6, Endocrine Society, 87th Annual Meeting, 4-7 June 2005, San Diego.

Received 8 July 2005

Accepted 13 September 2005 